\title{
Expression of infectious murine leukemia viruses by RAW264.7 cells, a potential complication for studies with a widely used mouse macrophage cell line
} Janet W Hartley*1, Leonard H Evans², Kim Y Green ${ }^{3}$, Zohreh Naghashfar ${ }^{1}$, Alfonso R Macias ${ }^{1}$, Patricia M Zerfas ${ }^{4}$ and Jerrold M Ward ${ }^{* 5}$

Address: ${ }^{1}$ Laboratory of Immunopathology, NIAID, NIH, Bethesda, MD 20892, USA, ${ }^{2}$ Laboratory of Persistent Viral Diseases, Rocky Mountain Laboratories, NIAID, NIH, Hamilton, MT 59840, USA, ${ }^{3}$ Laboratory of Infectious Diseases, NIAID, NIH, Bethesda, MD 20892, USA, ${ }^{4}$ Division of Veterinary Resources, Office of Research Services, Office of the Director, NIH, Bethesda, MD 20892, USA and ${ }^{5}$ Comparative Medicine Branch, NIAID, NIH, Bethesda, MD 20892-8135, USA

Email: Janet W Hartley* - jhartley@niaid.nih.gov; Leonard H Evans - levans@niaid.nih.gov; Kim Y Green - kgreen@niaid.nih.gov; Zohreh Naghashfar - znaghash@niaid.nih.gov; Alfonso R Macias - am327e@nih.gov; Patricia M Zerfas - zerfasp@ors.od.nih.gov; Jerrold M Ward* - jw116y@nih.gov

* Corresponding authors

Published: 4 January 2008

Retrovirology 2008, 5:I doi:10.1186/1742-4690-5-1
Received: 7 November 2007

Accepted: 4 January 2008

This article is available from: http://www.retrovirology.com/content/5/I/I

(c) 2008 Hartley et al; licensee BioMed Central Ltd.

This is an Open Access article distributed under the terms of the Creative Commons Attribution License (http://creativecommons.org/licenses/by/2.0), which permits unrestricted use, distribution, and reproduction in any medium, provided the original work is properly cited.

\begin{abstract}
The mouse macrophage-like cell line RAW264.7, the most commonly used mouse macrophage cell line in medical research, was originally reported to be free of replication-competent murine leukemia virus (MuLV) despite its origin in a tumor induced by Abelson MuLV containing Moloney MuLV as helper virus. As currently available, however, we find that it produces significant levels of ecotropic MuLV with the biologic features of the Moloney isolate and also MuLV of the polytropic or MCF class. Newborn mice developed lymphoma following inoculation with the MuLV mixture expressed by these cells. These findings should be considered in interpretation of increasingly widespread use of these cells for propagation of other viruses, studies of biological responses to virus infection and use in RNA interference and cell signalling studies.
\end{abstract}

\section{Background}

In contrast to most other mouse-derived cell cultures, the macrophage-like cell line RAW264.7 [1] supports replication of murine noroviruses and is widely used for this purpose [2]. Further, in studies of a mouse model of severe respiratory disease, RAW264.7 was found to be uniquely efficient for propagation of the causative agent, pneumonia virus of mice, and for measuring infection-related proinflammatory mediators [3]. In addition, because of ease of cell propagation, high efficiency for DNA transfection, sensitivity to RNA interference [4], possession of receptors for many relevant ligands, and other properties,
RAW264.7 has been chosen by the Alliance for Cellular Signaling as the primary experimental system for their large-scale study of signaling pathways [5]. The RAW264.7 cell line was derived about 30 years ago from a tumor developing in a $\mathrm{BAB} / 14$ mouse, a $\mathrm{BALB} / \mathrm{c}$ IgH congenic strain, inoculated with Abelson murine leukemia virus (MuLV), a defective transforming virus containing the $\mathrm{v}$ abl tyrosine kinase oncogene, and replication-competent Moloney (Mo-MuLV) that served as helper virus [1]. At the time it was described, tests for presence of replication competent virus were negative and cells in the American Type Culture Collection repository (ATCC TIB-71) were 
so designated until recently. As far as we can determine, ATCC is the major if not sole, commercial source of this cell line. To date, a Pubmed retrieval lists over 1500 publications that have used the RAW264.7 cell line in the research reported.

\section{Results and conclusion}

In the course of evaluating RAW264.7 cells for use in isolation and propagation of new isolates of murine norovirus, electron microscopy revealed particles with C-type morphology (data not shown). To look for expression of MuLV-encoded protein, RAW264.7 cell pellets were fixed in formalin and embedded in paraffin; after antigen retrieval using proteinase $\mathrm{K}$, sections were stained by avidin-biotin immunohistochemistry (IHC) using groupreactive goat anti-Rauscher MuLV p30 antibody (from the Division of Cancer Cause and Prevention, NCI, Frederick, MD and obtained from Dr. Sandra Ruscetti). Abundant expression of MuLV p30 was revealed (Figure 1). Cell surface expression of MuLV gp70 protein (SU) was revealed by immunofluorescence assay using the broadly reactive monoclonal antibody 83A25 [6] (data not shown).

In tests for the presence of infectious MuLV, cell-free harvests of RAW264.7 supernatants from two separate acquisitions from ATCC were positive using the XC plaque assay [7] in SC-1 cells [8], indicating the presence of virus of the ecotropic MuLV class. Titers of several independent harvests ranged from $10^{1.2}$ to $10^{4.2} \mathrm{XC}$ plaque-forming units (pfu) per ml. Lower titers were associated with high density cell growth and consequent low $\mathrm{pH}$ (data not shown).

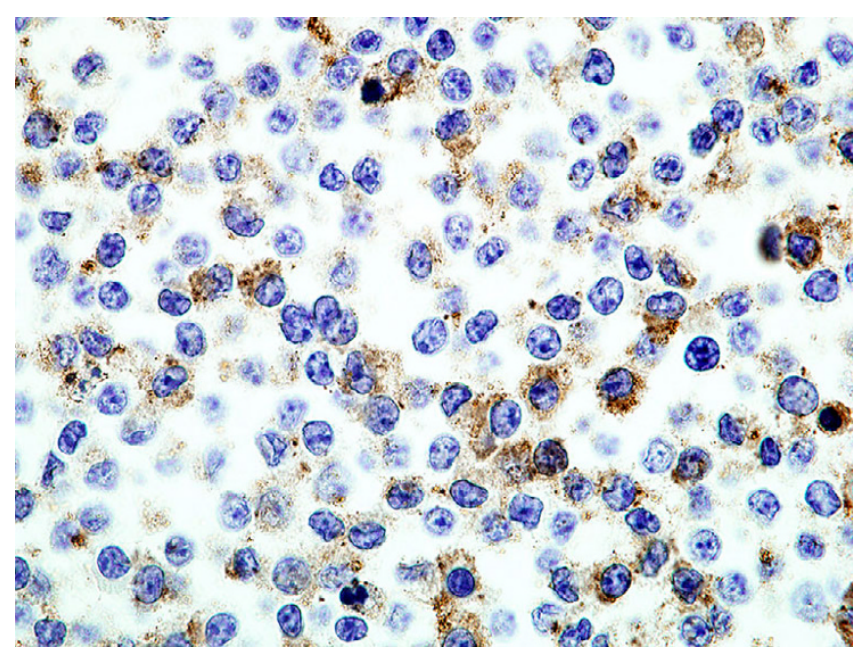

\section{Figure I}

MuLV p30 expressed by RAW264.7 cells in a formalin-fixed, paraffin-embedded cell pellet. (Avidin biotin IHC, $\times 1000$ ).
Infection of cell cultures of various mouse strains by most ecotropic MuLVs is regulated by the Fv1 genotype of the mouse and the tropism of the virus. Thus, $F v 1^{n}$ cells are permissive for $\mathrm{N}$-tropic and partially restrictive for $\mathrm{B}$ tropic MuLVs; the reciprocal pattern is observed for cells of $F v 1^{b}$ mice. A few isolates with long laboratory passage histories, including Mo-MuLV, are not restricted by either allele and are termed NB-tropic. XC plaque titration of RAW264.7 supernatant in NIH3T3 $\left(F v 1^{n}\right)$ and BALB3T3 $\left(F v 1^{b}\right)$ cells gave essentially identical titers $\left(10^{4.1}\right.$ and $10^{4.2}$, respectively) indicating NB-tropism. Additionally, focal immunofluoresence assays (IFA) [9] utilizing monoclonal hybridoma antibody mAb538, specifically reactive with the Mo-MuLV envelope (SU) protein [10], were positive in NIH3T3 cells and to about 1000-fold lower titer in Mus dunni cells, confirming the presence of a virus with ecotropic Mo-MuLV biological properties. Why earlier tests failed to detect ecotropic MuLV in RAW264.7 cells is unknown but possible explanations include differences in culture conditions and the health of the cells when assayed or in sensitivity of the tests used in different laboratories at different times.

It is well established that mouse-passaged ecotropic MuLV stocks, like the Mo-MuLV helper virus used in establishing RAW264.7 [1], frequently contain MuLV of other classes xenotropic and recombinant MuLVs that result from interaction between ecotropic sequences and polytropic, also referred to as $\mathrm{MCF}$, proviral sequences. Indeed, isolates of these classes were reported in a stock of Abelson MuLV complex [11]. Comparative IFA titrations of a RAW264.7 supernatant were performed in NIH3T3 cells using antiMo-MuLV mAb538 and two mAbs that specifically detect polytropic MuLV SU antigen: 514, reactive with all tested polytropic MuLVs [11], and HY7, reactive with certain polytropic subsets $[12,13]$. Titer estimates of $10^{4}$ and $10^{4.5}$ ffu per ml were obtained for polytropic and Moloney ecotropic MuLVs, respectively. Negative results with mAbs reactive with xenotropic MuLVs indicated no significant population of this class in RAW264.7 supernatants (data not shown). Thus, RAW264.7 cells express approximately equal levels of ecotropic Moloney-like and polytropic MCF MuLVs, with some variation in titer probably depending on culture conditions.

Inoculation of neonatal mice of sensitive strains with MoMuLV results in development of almost exclusively $\mathrm{T}$ cell lymphoblastic lymphomas (LL), mostly of thymic origin. To determine the pathogenic potential of harvests from RAW264.7 cells, we inoculated 1-2 day old Cr:NIH(S) (NIH Swiss) and BALB/cAnNCr (BALB/c) mice, $0.02 \mathrm{ml}$ intraperitoneally and in the region of the thymus with a filtered supernatant of RAW264.7 cells or 264.7 SC-1, a harvest of SC-1 cells infected with RAW264.7 supernatant and passaged twice. For comparison, mice were similarly 
Table I: Comparative Pathogenicity of 264.7MuLVs and Mo-MuLV in Mice

\begin{tabular}{|c|c|c|c|c|c|c|c|c|c|}
\hline \multirow[b]{2}{*}{$\begin{array}{l}\text { Mouse } \\
\text { Strain }\end{array}$} & \multirow[b]{2}{*}{ Inoculum } & \multirow[b]{2}{*}{ Virus dose ${ }^{1}$} & \multirow[b]{2}{*}{ \#pos/\#inoc ${ }^{2}$} & \multirow[b]{2}{*}{$\begin{array}{c}\text { Latency } \\
\text { (days) }\end{array}$} & \multicolumn{5}{|c|}{ Diagnosis $^{3}$} \\
\hline & & & & & $\%$ positive & LL-T & LL-B & Erythroid & Other \\
\hline \multirow[t]{6}{*}{ NIH Swiss } & Mo-MuLV & 104.4 & $6 / 6$ & $87+/-16$ & 100 & 4 & 0 & $2^{4}$ & 0 \\
\hline & & 102.2 & $10 / 10$ & $93+/-13$ & 100 & 10 & 0 & 0 & 0 \\
\hline & RAW264.7 cell-free supernatant & $10^{1.0}$ & $5 / 7$ & $259+/-68$ & 71 & 3 & 0 & I & $1^{5}$ \\
\hline & & 102.5 & $12 / 15$ & $163+/-68$ & 80 & 5 & 4 & 3 & 0 \\
\hline & 264.7-MuLV, SC-I passage & $10^{2.2}$ & $3 / 3$ & $146+/-24$ & 100 & 2 & I & 0 & 0 \\
\hline & None & - & $0 / 5$ & & & & & & \\
\hline \multirow[t]{5}{*}{$\mathrm{BALB} / \mathrm{c}$} & Mo-MuLV & $10^{4.4}$ & $5 / 5$ & $98+/-14$ & 100 & 5 & 0 & 0 & 0 \\
\hline & RAW264.7 cell-free supernatant & $10^{1.0}$ & $2 / 2$ & 255 & 100 & I & 0 & I & 0 \\
\hline & & 102.5 & $7 / 12$ & $168+/-53$ & 58 & 4 & $2^{4}$ & I & 0 \\
\hline & 264.7-MuLV SC-I passage & $10^{2.2}$ & $5 / 5$ & $216+/-84$ & 100 & 4 & 0 & 0 & 16 \\
\hline & None & - & $0 / 4$ & & & & & & \\
\hline
\end{tabular}

\footnotetext{
I pfu/mouse of ecotropic MuLV, based on XC plaque titration in SC-I cells; polytropic MuLV titer not determined.

2 number of mice positive for hematopoietic disease/number inoculated.

${ }^{3}$ LL, lymphoblastic lymphoma;, T, T-cell lineage; B, B-cell lineage; erythroid, erythroleukemia (PAX5 and CD3 negative).

${ }^{4}$ One case also had early Thymic T-LL.

5 Mast cell tumor, spleen and bone marrow (366d post-inoculation).

${ }^{6}$ Early splenic marginal zone lymphoma (295d post-inoculation) ; also very early T-LL in thymus.
}

inoculated with Mo-MuLV (molecularly cloned and propagated in SC-1 cells). Controls were uninoculated mice of the same strains. Mice were obtained from the Division of Cancer Treatment, NCI, Frederick, MD and studied under NIAID Animal Care and Use Committee approved protocols and housing. Mice were observed for 8 to 12 months and necropsied when signs of splenomegaly, lymphadenopathy, labored breathing or lethargy were noted or the experiment was terminated at 12 months. Diagnosis was based on gross findings, microscopic examination of H\&E stained formalin fixed, paraffin embedded tissues or studied by IHC using the anti-p30 antibody, anti-CD3 for Tcell lineage identification (DAKO Corporation, Carpinteria, CA Catalog \# A452), and anti-PAX5 for B-cell lineage (Goat anti-Pax 5, Santa Cruz Biotechnology, Santa Cruz, CA, Catalog \#sc-1974) [14]. Criteria for histopathological diagnosis were as described [15].

As shown in Table 1, there were no significant differences in tumor incidence between NIH Swiss and BALB/c recipients but virus dose was clearly an important variable for those inoculated with the viruses produced by RAW264.7 cells (264.7MuLVmix), with higher concentrations tending to give shorter latencies and more diversity in pathology. Mo-MuLV induced mostly T-cell LL, characterized histologically by diffuse growth of $\mathrm{CD}^{+}{ }^{+} \mathrm{T}$-cell lymphoblasts usually originating in the thymus and metastasizing to the spleen, liver and other organs. Most mice presented with significantly enlarged thymus (16/19), spleen weights of over $600 \mathrm{mg}(18 / 19)$ and variable lymphadenopathy. Mice injected with 264.7-MuLVmix expressed MuLV p30 in spleen (Figure 2), megakaryocytes, and many tissues prior to tumor development and in all lym- phomas examined (e.g., Figure 3). Splenomegaly and lymphadenopathy were variable with spleen weights ranging from 100 to $1800 \mathrm{mg}$. The majority of hematopoietic neoplasms were classified as LL (26/34). Of these, 19 were of T-cell origin, CD3+ and PAX5; 13 were associated with enlarged thymus (Figure 4). In contrast to $\mathrm{CD} 3+\mathrm{Mo}-\mathrm{MuLV}$-induced LL (Figure 5), the remaining seven LL were of B-cell origin, based on PAX5 ${ }^{+}$IHC (Figure 6) and CD3 negativity. Spleen weights ranged from 450 to $770 \mathrm{mg}$ and lymph node size was variable. In addition, one BALB/c mouse had an early splenic marginal

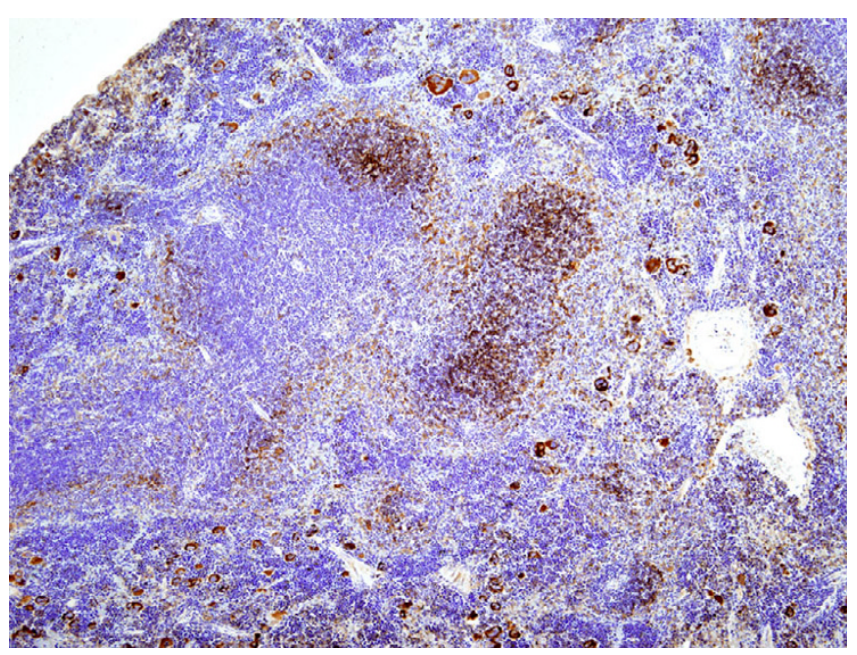

Figure 2

MuLV p30 expression in spleen 8 weeks post injection of 264.7-MuLV, SC-I prior to lymphoma development (IHC, hematoxylin, $\times 100$ ). 


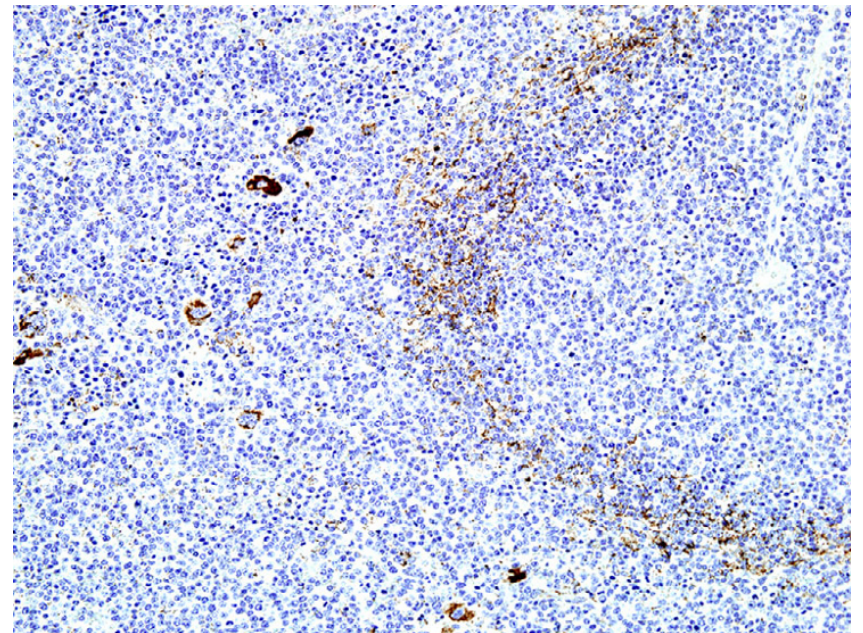

Figure 3

MuLV p30 in splenic follicular B-cells and megakaryocytes in a mouse injected with 264.7-MuLV and that developed thymic lymphoma at II9 days (IHC, hematoxylin, $\times 200$ ).

zone B cell lymphoma (MZL) as well as early thymic T-LL. To our knowledge, spontaneous splenic MZL has not been reported in this strain. There are sporadic reports of exogenous virus induction of $\mathrm{B}$ cell lymphomas in mice by a variety of ecotropic and polytropic MuLVs [16,17], none to our knowledge involving Mo-MuLV except for pre-B LL induction in E $\mu$ - $m y c$ transgenic mice [18]. Pre-B, immature B cells and plasma cells are the target cells of Abelson MuLV [19] and mice infected with the LP-BM5 complex, which includes a defective immunodeficiency-inducing virus, develop transplantable clonal B-cell populations [20]. We did not detect Abelson transforming capacity in tissue culture assays (data not shown), but it is conceivable that B-cell LLs found in our study might be causally related to the Abelson genome present in RAW264.7 cells.

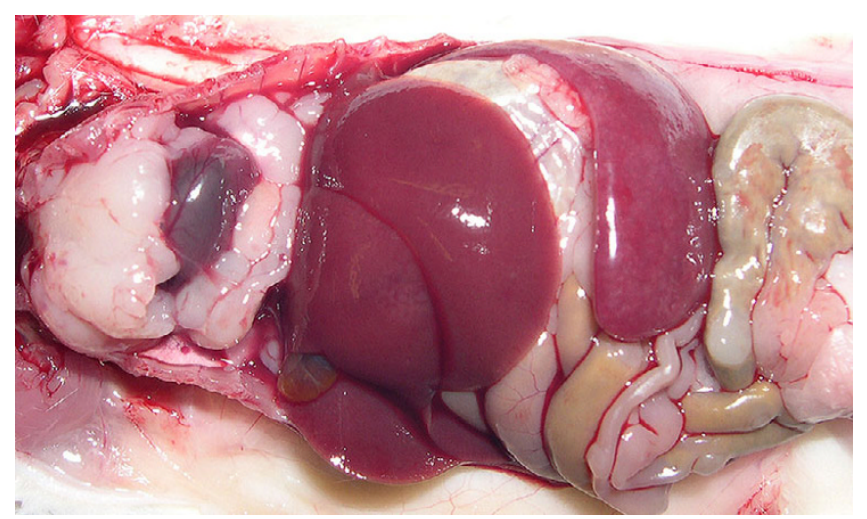

Figure 4

Thymic lymphoma induced by 264.7-MuLV, 164 days post injection. Note large spleen.

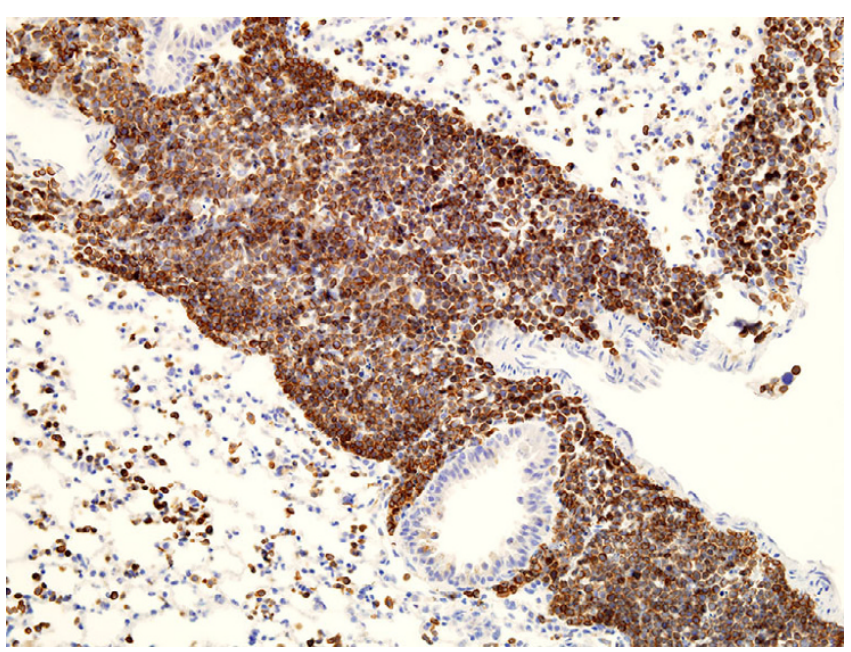

Figure 5

Thymic lymphoma in 264.7-MuLV infected mouse showing $\mathrm{CD}^{+}$lymphoma cells in lung metastases (IHC, hematoxylin, $\times 200$ ).

Alternatively, B cell pathology may be associated with the polytropic virus population present in RAW264.7 supernatants, likely in synergy with Mo-MuLV. Further testing with cloned virus preparations would be necessary to resolve these possibilities.

Six of $34264.7 \mathrm{MuLVmix}$ - and 2 of 16 MoMuLV-induced tumors were non-lymphoid and diagnosed as erythroleukemia based on splenomegaly with a high frequency of erythroid cells and lack of reactivity with CD3 and PAX5. These neoplasms, not usually seen following Mo-MuLV

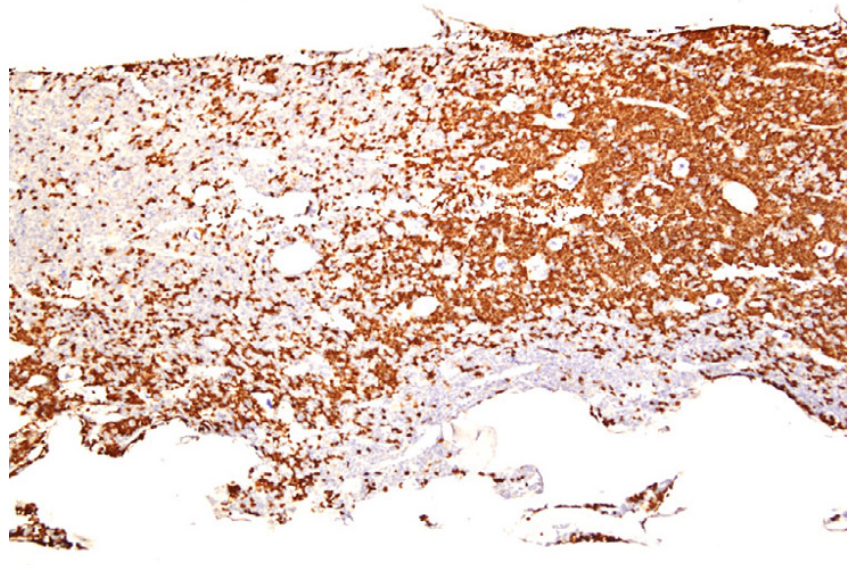

Figure 6

PAX5 expression in bone marrow metastases of a B-cell lymphoma induced by RAW 264.7-MuLV (IHC, hematoxylin, $\times 100)$. 
infection, may be related to the generalized hyperplasia of hematopoietic lineages, including erythroid, reported in pre-leukemic Mo-MuLV-infected mice [21].

A further unusual finding was a mast cell tumor, a rarely seen mouse neoplasm that cannot unequivocally be considered related to the virus inoculation.

As shown in this report, RAW264.7 cells as currently available from ATCC express ecotropic and polytropic MuLVs. The ecotropic virus has biological properties of the MoMuLV helper virus of the Abelson virus complex that induced the tumor from which the cell line derived. Cellfree culture supernatants containing the mixed virus population induced hematopoietic disease in newborn mice, primarily LL that were mostly of T cell type, as is characteristic of Mo-MuLV lymphomagenesis, but also some of B cell origin. This tumor-inducing potential may confound pathogenicity testing of unrelated viruses propagated in RAW264.7, especially in newborn mice. Adult mice are susceptible to infection by Mo- and other MuLVs, however [22,23], and mixed infection of MuLVs with related and unrelated viruses may have effects not directly attributable to lymphomagenicity. For example, radiation-induced RadLV enhances expression of MHC Class I genes [24] as does Mo-MuLV in cell culture [25]. Synergism between different retroviruses of low pathogenicity induces a rapidly fatal neurological disease [26], ecotropic MuLV potentiates LDV-related paralytic disease [27] and Mo-MuLV potentiates polyomavirus-induced runting syndrome [28].

Ecotropic MuLV infection of adult mice has been shown to increase B-cell proliferation, serum immunoglobulin $M$ levels and expression of transcripts associated with B cell activation [23]. Further, infection of bone marrow cells with MoMuLV or bone marrow and primary B cells by Abelson MuLV induces expression of activation-induced cytidine deaminase (AID) by activating NFKB $[29,30]$. Ectopic expression of AID can result in generalized somatic hypermutation [31].

Such illustrations of unanticipated consequences of MuLV infection as well as conceivable disruptive effects of MuLV replication, including integration into cellular DNA and cell surface expression of MuLV antigens, suggest caution in experimental design and data interpretation in studies utilizing RAW264.7 cells.

\section{Abbreviations}

MuLV: Murine leukemia virus;

Mo-MuLV: Moloney MuLV;

IFA: Immunofluorescence focus assay;
LL: Lymphoblastic lymphoma;

IHC: Immunohistochemistry.

\section{Competing interests}

The author(s) declare that they have no competing interests.

\section{Authors' contributions}

JMW, KYG and JWH conceived and designed the study. JMW performed histopathological observations and carried out IHC studies. LHE carried out focal IFA. ZN performed cell culture and viral quantitation studies. PZ performed electron microscopy and first found the virus particles. AM, JWH and JMW carried out mouse studies. JWH and JMW drafted the paper.

\section{Acknowledgements}

This work was supported in part by the Intramural Research Program of the National Institutes of Health, National Institute of Allergy and Infectious Diseases and Divisions of Research Services, Office of the Director, and, in part, by a NIAID contract to SoBran, Inc. We thank Dr. Torgny N. Fredrickson for helpful diagnostic consultations and discussions. We are also thankful for the excellent assistance of Elizabeth M. Williams, Lawrence J. Faucette, Frank Malik and Dr. Lily I. Cheng. Dr. Sandra Ruscetti, NCl, kindly provided the anti-Rauscher p30 goat antiserum. Dr. Bruce Chesebro, NIAID, kindly provided MAb 538.

\section{References}

I. Raschke WC, Baird S, Ralph P, Nakoinz I: Functional macrophage cell lines transformed by Abelson leukemia virus. Cell 1978, I 5:261-267.

2. Wobus CE, Karst SM, Thackray LB, Chang K-O, Sosnovtsev SV, Belliot G, Krug JM, Green KY, Virgin HWIV: Replication of Norovirus in cell culture reveals a tropsim for dendritic cells and macrophages. PloS Biology 2004, 2:2076-2084.

3. Dyer KD, Schellens IMM, Bonville CA, Martin BV, Domachowske JB, Rosenberg HF: Efficient replication of pneumonia virus of mice (PVM) in a mouse macrophage cell line. Virol Journal 2007, 4:48-5I.

4. Shin J-J, Wall EA, Zavzavadjian JR, Santat LA, Liu J, Hwang J-I, Rebres R, Roach T, Seaman W, Simon MI, Fraser IDC: A single lentiviral vector platform for microRNA-based conditional RNA interference and coordinated gene expression. Proc Natl Acad Sci USA 2006, 103:13759-13764.

5. [http://www.signaling-gateway.org/aboutus/CellPrepLab.html]

6. Evans LH, Morrison RP, Malik FG, Portis J, Britt W]: A neutralizable epitope common to the envelope glycoproteins of ecotropic, polytropic, xenotropic, and amphotropic murine leukemia viruses. J Virol 1990, 64(1 2):6176-6183.

7. Rowe WP, Pugh WE, Hartley JW: Plaque assay techniques for murine leukemia viruses. Virology 1970, 42: I I36-I I39.

8. Hartley JW, Rowe WP: Clonal cell lines from a feral mouse embryo which lack host-range restriction for murine leukemia viruses. Virology 1975, 65:128-134.

9. Sitbon M, Nishio J, Wehrly D, Lodmell D, Chesebro B: Use of a focal immunofluorescence assay on live cells for quantitation of retroviruses: distinction of host range classes in virus mixtures and biological cloning of dual-tropic murine leukemia viruses. Virology 1985, I4I:I I0-I I8.

10. Lavignon M, Evans LH: A multistep process of leukemogenesis in Moloney murine leukemia virus-infected mice that is modulated by retroviral pseudotyping and interference. J Virol 1996, 70:3852-3862.

II. Chang KSS, Log T, Bandyopadhyay AK: Characterization of xenotropic and dual-tropic type $C$ retroviruses isolated from Abelson tumour. J Gen Virol 1982, 58: I I5- 125. 
12. Chesebro B, Britt W, Evans L, Wehrly K, Nishio J, Cloyd M: Characterization of monoclonal antibodies reactive with murine leukemia viruses: use in analysis of strains of Friend MCF and Friend ecotropic murine leukemia virus. Virology 1983, | 27: | 34- | 48.

13. Cloyd MW, Chesebro B, Portis JL, Weir M: MCF-specific murine monoclonal antibodies made against AKR-247 MCF virus recognize a unique determinant associated with the gp70p I 5(E) complex. J Virol 1982, 4 I: I I I2- I I I7.

14. Ward JM, Erexson CR, Faucette LJ, Foley JF, Diikstra C, Cattoretti G: Immunohistochemical markers for the rodent immune system. Toxicol Pathol 2006, 34:616-630.

15. Morse HC, Anver MR, Fredrickson TN, Haines DC, Harris AW, Harris NL, Jaffe ES, Kogan SC, MacLennan IC, Pattengale P, Ward JM Bethesda proposals for classification of lymphoid neoplasms in mice. Blood 2002, 100:246-258.

16. Vasmel WLE, Zijlstra M, Radaszkiewicz T, Leupers CJM, de Goede REY, Melief CJM: Major histocompatibility complex class IIregulated immunity to murine leukemia virus protects against early T-cell but not late B-cell lymphomas. J Virol I 988, 62:3156-3166.

17. Lovmand J, Sorensen AB, Schmidt J, Ostergaard M, Luz A, Pedersen FS: B-cell lymphoma induction by Akv murine leukemia viruses harboring one or both copies of the tandem repeat in the U3 enhancer. J Virol 1998, 72:5745-5756.

18. van Lohuizen M, Verbeek S, Scheijen B, Wientjens E, van der Guiden $\mathrm{H}$, Berns $\mathrm{A}$ : Identification of cooperating oncogenes in $E \mu-m y c$ transgenic mice by provirus tagging. Cell 1991, 65:737-752.

19. Rosenberg N, Baltimore D: A quantitative assay for transformation of bone marrow cells by Abelson leukemia virus. J Exp Med 1976, I43: |453-|463.

20. Tang Y, Chattopadhyay SK, Hartley JW, Fredrickson TN, Morse HC III: Clonal outgrowths of $T$ and $B$ cells in SCID mice reconstituted with cells from mice with MAIDS. In Vivo 1994 8:953-960.

21. Davis BR, Brightman BK, Chandy KG, Fan H: Characterization of a preleukemic state induced by Moloney murine leukemia virus: Evidence for two infection events during leukemogenesis. Proc Natl Acad Sci 1987, 84:4875-4879.

22. Gisselbrecht S, Pozo F, Debre P, Hurot MA, Lacombe MJ, Levy JP. Genetic control of sensitivity to Moloney-virus-induced leukemias in mice. I. Demonstration of multigenic control. Int J Cancer 1978, 2 I:626-634.

23. Lee JS, Giese NA, Elkins KL, Yetter RA, Holmes KL, Hartley JW, Morse HC III: Effects of exogenous, nonleukemogenic, ecotropic leukemia virus infections on the immune systems of adult C57BL/6 mice. J Virol 1995, 69:4182-4188.

24. Meruelo D, Nimelstein SH, Jones PP, Lieberman M, McDevitt HO: Increased synthesis and expression of $\mathbf{H - 2}$ antigens on thymocytes as a result of radiation leukemia virus infection: $A$ possible mechanism for $\mathbf{H}-2$ linked control of virus-induced neoplasia. J Exp Med 1978, I47:470-487.

25. Wilson LD, Flyer DC, Faller DV: Murine retroviruses control Class I major histocompatibility antigen gene expression via a trans effect at the transcriptional level. Mol Cell Bio 1987, 7:2406-24I5.

26. Evans LH, Lavignob M, Peterson K, Hasenkrug K, Robertson S, Malik $\mathrm{F}$, Virtaneva K: In vivo interactions of ecotropic and polytropic murine leukemia viruses in mixed virus infections. J Virol 2006, 80:4748-4757.

27. Anderson GW, Palmer GA, Rowland RRR, Even C, Plagemann PGW: Infection of central nervous system cells by ecotropic murine leukemia virus in C58 and AKR mice and in in uteroinfected $C E / J$ mice predisposes mice to paralytic infection by lactate dehydrogenase-elevating virus. J Virol 1995, 69:308-319.

28. Atencio IA, Belli B, Hobbs M, Cheng SF, Villarreal LP, Fan H: A model for mixed virus disease: co-infection with Moloney murine leukemia virus potentiates runting induced by polyomavirus (A2 strain) in BALB/c and NIH Swiss mice. Virology 1995 2 I 2:356-366.

29. Gourzi P, Leonova T, Papavasiliou FN: Viral induction of AID is independent of the interferon and the Toll-like receptor signalling pathways but requires NF-кB. J Exp Med 2007, 204:259-265.
30. Gourzi P, Leonova T, Papavasiliou FN: A role for activationinduced cytidine deaminase in the host response against a transforming retrovirus. Immunity 2006, 24:779-786.

31. Yoshikawa K, Okazaki IM, Eto T, Kinoshita K, Muramatsu M, Nagaoka $H$, Honjo $T$ : AID enzyme-induced hypermutation in an actively transcribed gene in fibroblasts. Science 2002, 296:2033-2036.
Publish with Biomed Central and every scientist can read your work free of charge

"BioMed Central will be the most significant development for disseminating the results of biomedical research in our lifetime. "

Sir Paul Nurse, Cancer Research UK

Your research papers will be:

- available free of charge to the entire biomedical community

- peer reviewed and published immediately upon acceptance

- cited in PubMed and archived on PubMed Central

- yours - you keep the copyright
BioMedcentral 